\title{
AUTO ACCIDENT COMPENSATION IN ALBERTA: TOWARD PEACEFUL COEXISTENCE?
}

\author{
ALLEN M. LINDEN*
}

Tort law as a means of reparation for victims of automobile accidents in Alberta has recently been subject to criticism because of its many defects. The author examines both the defects and the advantages of the present system of compensation, and, concluding that it is unsatisfactory proceeds to make a proposal for reform based on the peaceful coexistence of tort law and an automobile accident compensation plan.

Reform is in the air. Across Canada (and indeed throughout the world) legislators, lawyers, academics and insurance executives are reexamining the foundations of their automobile accident reparation systems. There have been royal commissions in British Columbia and Nova Scotia, select committees of the legislature in Ontario, Manitoba and Alberta and less formal studies have been undertaken elsewhere. It is right that this concern has been evinced, for the problem of automobile insurance, along with the wider question of automobile accidents, is a perplexing one to anyone who studies it. After all, the social costs created when the lives of over 100,000 human beings are snuffed out annually around the world and millions more are maimed are enormous. In Alberta alone 395 people were killed and 9,271 injured in 42,640 accidents in 1967. 1

The Province of Alberta has mainfested its concern in its Report of the Legislative Committee Appointed to Examine into Matters Relating to Automobile Insurance. ${ }^{2}$ In 1966, this Committee, recognizing the multi-faceted nature of the problem, urged the mandatory installation of safety features into all automobiles, the removal of incompetent and irresponsible drivers from the roads, better driver training, improved highway engineering, tougher enforcement of traffic laws, encouragement to safety programs, improved vehicle testing and other such items. This was wise, because it manifests an appreciation of the central dilemma facing automobile insurance companies-that insurance premiums must reflect the cost of accidents. In other words, when the number of accidents increases, the rates insurers charge motorists must rise. And, as a corollary of this, insurance premiums cannot be lowered significantly unless the number and severity of accidents is reduced.

But, although it is unwise to separate the problem of auto insurance from the problem of auto accidents, ${ }^{3}$ the purpose of this paper is to focus on the matter of compensation for those injured in car crashes. It must be recognized that, whatever we do to diminish accidents, we shall never be able to end them completely. Therefore, there will always be a need to provide economic aid to the victims.

The primary method of allocating the losses generated by automobile accidents is the law of torts, which stipulates simply that those who

* B.A., LL.M. (Calif.), J.S.D. (Calif.), Professor of Law, Osgoode Hall Law School of York University.

1 Alberta Safety Council 1967 The committee was composed of Messrs. Taylor, (Chairman), Senych, Benoit, Ludwig, Henderson, Hinman, Lamothe, Delday, Maccagno and Switzer.

3 See generally on this problem, Linden, The Prevention of Automobile Accidents (1967), 15 Chitty's L.J. 80. 
negligently injure others must reimburse them for any costs incurred. Consequently, if someone is injured without anyone being at fault, or as a result of his own fault, tort law turns its back on him. If, however, the injury results from the negligence of both the injured plaintiff and the defendant, the plaintiff may collect in tort but the amount of his recovery is reduced in the proportion that his negligence contributed to the accident.

Now this tort system has been under severe attack of late by torts professors, some lawyers, governmental officials and others. ${ }^{4}$ Among these critics has been the Alberta Select Committee that, in 1966, endorsed the principle of "compensation regardless of fault" and urged the adoption of a plan for "peaceful coexistence". In the months ahead Albertans must decide whether they will accept this proposal or whether they will reject it. To assist in this decision, this paper will consider both the complaints levelled against the present system and the things said in its defence. Finally, some conclusions will be drawn.

\section{WHAT IS WRONG WITH THE PRESENT SYSTEM?}

The main defect in the fault system is that it necessarily denies tort recovery to those whose injuries are due solely to their own negligence, to those whose injuries are produced by pure mischance and to those who are unable to prove that someone else was to blame for the accident. In order to measure the actual economic impact of this fault system on the individuals hurt in car crashes, the Osgoode Hall Law School conducted a statistical studys of individuals injured or killed in 1961 in the County of York, which contains about one-third of the population of Ontario as well as its capital city of Toronto. The research team conducted personal interviews with the injured individuals selected, their lawyers, doctors and hospitals, and the data was then coded and keypunched and processed through a computer. It was demonstrated that the tort system by itself falls far short of providing full economic reimbursement for all the injury victims. In fact, 57 per cent failed to recover anything via the tort route alone and the situation was worse in more serious cases than in minor ones. In part this poor result was due to the iniquitous Ontario guest passenger legislation, ${ }^{b}$ as a consequence of which 66 per cent of all passengers recovered nothing. This recovery pattern was, nevertheless, still better than that disclosed in some of the American studies where, for example, 63 per cent of the people of Michigan were denied tort recovery. ${ }^{7}$ It was not as good as the ratio of bodily injury claims paid in British Columbia, where 63 per cent were paid. ${ }^{8}$ The pattern of payment in British Columbia is better than Ontario largely because. the guest passenger laws in that Province (as well as those in Alberta) are more civilized than was Ontario's. In any event, if the sole goal of tort law is to compensate everyone injured (a questionable assumption), it has failed us miserably.

4 Keeton and O'Connell, Basic Protection for the Traffic Victim: A Blueprint for Reforming Automobile Insurance (1965); Ison, The Forensic Lottery (1967).

5 Linden, The Report of the Osgoode Hall Study on Compensation for Victims of Automobile Accidents (1965).

6 Section 105 (2), Highway Traffic Act, R.S.O. 1960, c. 261, provided for an absolute bar to guest passengers. It was amended recently to allow an action in cases of "gross negligence". Stat. Ont., 1966, c. 64, s. 20.

7 Conard et ai., Accident Costs and Payments 149, (1964).

8 Linden, The Processing of Automobile Claims (1967), 34 Ins. Couns. J. 50, 55. 
The spotty recovery pattern in Canada is in no way due to lack of insurance coverage, which at one time in our history was a significant bugbear. Today, if a Canadian is negligently struck by either an uninsured or hit-and-run driver in any of the ten provinces, he is still able to recover from some type of "unsatisfied judgment fund". The Province of Manitoba established the first Canadian "unsatisfied judgment fund". This government-operated fund guaranteed the payment of any automobile accident judgment or part thereof that remained unsatisfied above a specified minimum and below a certain maximum amount. Before long all of the other provinces followed suit; New Brunswick, Ontario, Saskatchewan and Alberta created government-operated schemes, like the one in Manitoba, whereas Newfoundland, Prince Edward Island, Nova Scotia, Quebec and British Columbia adopted systems operated collectively by the private insurance industry.

The Alberta legislation, The Motor Vehicles Accident Claims Act, ${ }^{9}$ is among the most advanced in Canada, if not the world. Modelled after the Ontario scheme, it establishes a Motor Vehicle Accident Claims Fund and enacts in s.7 (1) as follows:

Where a person has a cause of action against the owner or operator of an uninsured motor vehicle for damages for

(a) bodily injury to or the death of a person, or

(b) loss of or damage to property in an amount exceeding fifty dollars, arising out of the use or operation within Alberta of the motor vehicle, that person may apply to the Administrator, in the prescribed form, for payment out of the Fund in respect of the bodily injury or death, or loss of or damage to property.

If agreement with the uninsured motorist is reached, the Administrator may settle the claim. The Fund is then subrogated to the rights of the person to whom the money is paid and it may maintain an action for reimbursement. ${ }^{10}$ If there is no consent and no settlement, the injured person may sue the uninsured driver and, if notice is given to Administrator (who may defend the action), an application for payment may be made after judgment. ${ }^{11}$. The Fund is also available in the case of hit-and-run drivers, in which case the Administrator may be sued directly. There is a $\$ 35,000$ composite limit on payment out as well as a $\$ 50$ deductible for property loss and a set-off for other benefits obtained by the injured person. ${ }^{12}$ As a consequence of this legislation and, contrary to the claims of some uninformed critics, compulsory insurance legislation is a superfluous device in attempting to fill the compensation gap.

Another fault of the fault system is the problem of delay. Even where a victim of an automobile crash has a meritorious claim, he must wait too long for his award. This is a problem primarily of mass societies and large cities. In the United States there is an average delay of $\mathbf{3 1}$ months between the commencement of the action and the trial in the various metropolitan areas. It is even worse in the great cities, for example, the delay is 70 months in Chicago and 51 months in Philadelphia. ${ }^{13}$ In Canada the length of time it takes to get a trial is less than in the United States, but it is still too long to wait for more than 2 years in Toronto ${ }^{14}$ or for an

9 S.A. 1964, c. 56.

10 Ibid., s. 7 (4).

11 Ibid., ss. 8 and 9.

12 Ibid.

14 The Report of the Osgoode Hall Study, op. cit. supra, footnote 5. 
average of even one year, as is the case in Vancouver, British Columbia. ${ }^{15}$ In Alberta, the time it takes to get to trial, even in the major cities, should be slightly less than a year, which is good as these things go, but even this period cannot be viewed with smugness when someone is unable to work by reason of incapicity during this time. Nor would the addition of more judges and more courtrooms cut the waiting period appreciably in Canada (although it certainly would in the United States), for the delay is worse when there is injury, and still worse if it is severe, because it is necessary, when a lump sum award is being determined, to have a reliable medical prognosis prior to trial and this is seldom available until after several months. We should not forget, however, that the vast bulk of the claims, most of which are small, of course, are speedily settled without trial. A recent study in British Columbia ${ }^{16}$ disclosed that 73 per cent of all insurance claims were settled within 60 days of the time the insurer first learned of them. The bodily injury claims took longer, but even here 55 per cent were cleaned up within 90 days and 73 per cent within 6 months. The Michigan study ${ }^{17}$ also showed that 58 per cent of their injury cases were concluded in less than a year. The cases that linger for longer periods of time are the difficult ones that require litigation for resolution, where the evaluation of the injury is uncertain or where liability is in doubt. Fortunately, these cases are in the minority, but there is still too long a waiting period for payment and this period is longest where the need for payment is most pressing.

The cost of administering the tort system is too high. In the United States it takes $\$ 2.20$ in insurance premiums to put $\$ 1.00$ into the pocket of an injured person. This is so because American wages (and consequently administration costs) are generally higher, there is more inclination to litigate and less incentive to settle in America because virtually no costs are awarded and because the contingent fee system alone eats up one-third of the payments to the injured. In Canada the picture is somewhat brighter; it is calculated that two-thirds of each premium dollar is paid out in claims, a much better figure, although still less than the various welfare plans distribute. Legal fees are much lower also and contingent fees are outlawed.

There are also several peripheral complaints that are made. Fault is an uncertain concept, one argument goes, and the courts are required to try imaginary accidents because witnesses cannot give accurate evidence about complex traffic movements. Even if they could have at the time, they forget the facts by the time the trial arrives, and, even more disturbing, they tend to perjure themselves in order to win large verdicts. No doubt there is force in these contentions, but one gets the disturbing feeling that these criticisms prove too much; they go to the very roots of the adversary system and trial procedure as we know it, for it is doubtful whether witnesses are any more unobservant, forgetful or untruthful in criminal or in fraud trials. Because we have been so perplexed by the need to help auto accident victims, we have focussed on the motor vehicle trial, but before offering solutions, I fear that we must go deeper and analyze the totality of our judicial institutions. The point is that, in our

15 Linden, Automobile Cases in the British Columbia Courts (1967), 3 U.B.C.L. Rev. 194, 198.

10 See The Processing of Automobile Claims, op. cit. supra, footnote 8, at 54.

17 Op. cit. supra, footnote 7. 
attempts to solve the problem of the accident victim, we have unearthed larger problems which should not be swept under the rug.

This is no small list of deficiencies. The charges that have been made contain much truth, despite some exaggeration for dramatic effect. It is vital, however, to warn that the statements and work of Americans must not be accepted holus-bolus, for the situation in Canada is not nearly as bad as that in the United States. Nevertheless, there is much room for improvement in Canada.

\section{WHAT IS RIGHT ABOUT THE PRESENT SYSTEM?}

Despite these defects there are some aspects of the present auto compensation system that are worthy of preservation. A system that provides compensation for the majority of the injured, fairly promptly, at moderate cost need not be jettisoned completely. As far as the provision of reparation alone is concerned, tort law yields only about 60 per cent of the money collected by the auto victims studied; the balance of 40 per cent is paid by the various non-tort schemes that have sprung up over the last two decades. ${ }^{18}$ In assessing the efficacy of the present motor accident reparation system, we cannot ignore the important contribution made by hospital insurance, medical insurance (both public and private), life and accident insurance and even Workmen's Compensation. Working in partnership with tort law, these sources of recovery combined provided full economic compensation for 54 per cent of those suffering loss and, of the remaining under-compensated people, the out-of-pocket losses exceeded $\$ 500$ in only 7.2 per cent of all the injury cases. ${ }^{19}$ Now, although this falls short of perfect compensation, it is not too bad a record. Nevertheless, if the sole purpose of the present system is to cover all economic loss, it has failed and should be replaced by another method of distributing the costs of auto accidents.

However, tort law is concerned with more than mere compensation; it embodies other values that may make it worthwhile, despite the imperfect job it does in reimbursement for economic losses. First, tort law provides extra compensation for psychic losses or pain and suffering, something that welfare plans do not offer. It recognizes that each individual is unique and, consequently, it is tailored to treat each claimant as an individual. Some may scoff at the utility of this, but the ability to play golf or the piano, to smell a sizzling steak or to hear the sound of a symphony, although they may have no economic value, are prized by the person who is deprived of them.

Second, tort law is aimed at reducing accidents. Fault liability is supposed to deter negligent conduct by making those guilty of it pay damages to their victims. The increase of insurance coverage, however, is said to have diluted the prophylactic power of tort law, but, so far, there is no empirical proof of this. It may be that certain individuals are no longer deterred by the threat of civil sanctions while others continue to be. For example, there are, lamentably, still some drivers who are not insured and, presumably, insurance has not blunted their incentive to exercise care. In addition, some extra burden may be imposed on a negligent driver by civil liability, for example, since the loss he causes

18 The Report of the Osgoode Hall Study, op. cit. supra, footnote 5.

19 Ibid. 
may exceed the policy limits, it may not be covered by the policy at all, the policy may be cancelled altogether or the premium may be increased. Professor Fleming has even suggested that an increased premium might be a more effective sanction than a tort judgment because the latter often cannot be paid at all while the former must be if the person wishes to continue driving. ${ }^{20}$ In addition, the experience of being involved in civil litigation and of being marked publicly as the cause of injuring someone is seldom a pleasant one. An even more important deterrent may be the loss of his own tort recovery, either in whole or in part, by the negligent claimant. Moreover, by branding certain conduct as blameworthy, we may contribute something to the education of our people about the hazards of these activities. ${ }^{21}$ Nevertheless, all this discussion will remain pure theory until someone tests empirically the validity of these assumptions.

The law of torts is dedicated to the advancement of the notion of individual responsibility, an ideal that retains considerable force in western society. Thus, if someone by his faulty conduct causes an accident, it is felt that he should bear the consequences by paying the costs incurred by his victim. If it is he himself who is injured, he should be expected to shoulder his own expenses. According to Professor Keeton, ${ }^{22}$ most people feel it "just and fair" that the guilty, but not the innocent, pay, despite the fact that insurance undoubtedly dulls the impact of civil liability and social welfare mollifies that of bearing one's own loss.

Tort law helps to keep the peace, just as it was supposed to do in its formative days because it permits an aggrieved person to recover money in court rather than to spill blood on the streets. This "appeasement" function of tort law may, although it is speculative, still avoid some further injuries to members of society. Put another way, there are still people in this world who wish to secure revenge from those who injure them and who, if necessary, may resort to anti-social means to do so. By allowing a private tort remedy this urge for vengeance may be assuaged. ${ }^{23}$ That tort law rests in part upon such a psychoanalytical basis may be supported by the experience of the Soviet Union. ${ }^{24}$ After the revolution, the tort suit was abolished altogether there, but eventually it had to be re-instituted along with a ban on liability insurance. Another clue to indicate that tort law's roots may reach into the psyche may be our remarkable insistence upon the hypocritical retention of the tort suit against the individual defendent in form, despite the fact that in substance an insurance company is almost always the real defendant who retains counsel, defends the action and pays the judgment, if one is rendered against the individual defendant.

There is something else that tort law provides-the right of a human being to have his day in court-a day devoted exclusively to the consideration of his claim against another human being. The judge is there, and the jury (if one is permitted) is there, to listen to his complaint

20 The Role of Negligence in Modern Tort Law (1967), 53 Va. L. Rev. 815, 825

21 See Keeton, Is there a Place for Negligence in Modern Tort Law (1967), 53 Va. L. Rev. $886,889$.

22 Ibid. at 891.

23 See, generally, the perceptive and disturbing article by Ehrenzweig, A Psychonanalysis of Negligence (1963), 47 N.W.U.L. Rev. 855.

24 See Gray, Soviet Tort Law: The New Principles Annoted, [1964), U. of Ill. L.F. 180; See also Fleming, op. cit. supra, footnote 20 at 824 . 
and to render justice. In a society that is becoming increasingly depersonalized, computerized and, as a result, "alienated", we should hesitate long before removing the right to a trial. There is something of psychological value left in tort trials, something that ought not to be abandoned at a time when ombudsmen and charters of human rights are being demanded as an antidote to the oppression of the individual by "big government" and "big business". In a small way, it may be comforting to Canadians to know that, when they are injured, they, as individuals, are entitled to a full and open hearing before an independent tribunal and to a sober decision with reasons from which they may even appeal, if they wish.

But, in the long run, the most compelling argument asserted for the continuance of tort law may be that of "general deterrence," developed by Professor Calabresi of Yale University. ${ }^{25}$ By demanding that an activity pay its own way, society is able to make a more knowledgeable decision concerning the allocation of its resources. In other words, if motorists were made to pay the full costs of motoring, including the expenses of treating all traffic victims, some of them might give up driving and use a safer method of transportation where the cost of insurance will be less because it produces fewer accidents. Other motorists might decide to reduce their insurance rates through an alteration of their risk category; they might, therefore, stop driving to work or they might deny the car to their teenage sons. However, we may find that, rather than giving up their automobiles, some motorists will choose to drive without insurance coverage, which is by no means desirable. This general deterrence theory, consequently, purports to create an "incentive for loss prevention" that encourages enterprisers to minimize accidents so as to reduce their long term insurance costs, but unfortunately, this theory has not yet been buttressed by solid scientific data. Until the analysis of Professor Calabresi is tested by empirical research it will remain only a theory, albeit a beguiling one. Tort law is, therefore, not totally devoid of "relevance" in the modern world. Torts (unlike God) is not dead!

\section{WHAT SHOULD BE DONE?}

There are defects in the present system and there are strengths. To permit the status quo to continue would be unsatisfactory; to abolish tort law completely would be to deny us its attributes. The only solution, therefore, is peaceful coexistence-let there be an auto accident compensation plan and let tort law survive. Yes, this is a compromise or an accommodation, but one that improves what we have developed over the years without sacrificing anything. This principle has been enshrined in the Saskatchewan plan, the proposed Ontario plan, and most of the recent American plans, including the one by Keeton and O'Connell. ${ }^{2 a}$

25 The Decision for Accidents: An Approach to Non-Fault Allocation of Costs (1965), 78 Harv. L. Rev. 713; Blum and Kalven Public Law Perspectives on a Private Law Probiem-Auto Compensation Plans (1965), also (1964), 31 U. Chi. L. Rev. 641; Calabresi. Fault, Accidents and the Wonderful World of Blum and Kalven (1965), 75 Yale L.J. 216; Blum and Kalven. The Empty Cabinet of Dr. Calabresi-Auto Accidents and General Deterrence (1967), 34 U. Chi. L. Rev. 239.

20 See generally. Linden. Peaceful Coexistence and Automobile Accident Compensation (1966), 9 Can. Bar. J. 6. Keeton and O'Connell, however, propose to remove the right to damages for pain and suffering under $\$ 5,000.00$, something that may be necessary in the United States but not in Canada. 
It has also been followed, to a limited extent, in the Province of Alberta since 1947. Section 19 of the Motor Vehicle Accident Claims Act $^{27}$ permits the Fund to provide medical and rehabilitation care to anyone injured in an auto crash, regardless of fault. It stipulates:

In addition to other remedies provided by this Act a person who is injured on or after the first day of April, 1947, or

(a) by the operation of a motor vehicle driven by another person on or after the first day of April, 1947, or

(b) by the operation of a motor vehicle driven by himself on or after the first day of September, 1963,

to an extent requiring hospital or medical treatment or ambulance services may apply to the Administrator for reimbursement out of the Fund for the expenses and, where necessary, for the cost of appliances and treatments used in the complete or partial restoration of his muscular activity or co-ordination or to give him complete or limited mobility, and thereby to rehabilitate him.

Upon this promising, indeed exciting, foundation in Alberta there can be erected a peaceful coexistence plan. This is, in substance, what the Alberta Select Committee recommended in its 1966 report when it stated:

... the Committee endorses the principle of compensation regardless of fault providing it is made compulsory for all who carry P.L. and P.D. insurance. The Committee believes that this can become part of the standard automobile policy for basic accident benefits including

(a) payment for loss of life;

(b) limited medical payments resulting from injury;

(c) limited payment of weekly indemnity sufficient to provide the necessities of life while at the same time retaining the right of the individual to go to Court; if, however, a judgment is given by the Court, then the amount paid in compensation would be deducted from the Judgment.

The Insurance Industry has prepared a plan along these lines and only legislation is required to implement same. It is believed that, while this would add additional benefits and additional costs, it would greatly reduce the present costs involved in Court action, and in litigation, as well as relieve the present congestion in Courts.

Such a scheme would provide therefore, in addition to those benefits already given by the Alberta fund, payments in case of death and a subsistence income, something that is sorely needed by many of the victims of serious crash injuries. Unlike the Saskatchewan plan and the present Alberta system, however, the suggestion of the Alberta committee envisages this coverage being offered by private insurers, along with each basic automobile policy.

It may surprise some to learn that this plan is basically the same one recommended by the All Canada Insurance Federation, a body that represents the bulk of the insurance industry, to the British Columbia Royal Commission in December of 1966 and the same one urged by them upon the Superintendents of Insurance for nearly a decade. Alberta, and almost all of the other provinces, have already amended their legislation $^{28}$ to permit such "limited accident benefits" on a voluntary basis, but it has nowhere been proclaimed into force as yet. Before this is done, the new type of insurance should be made a mandatory part of every policy sold.

The most promising thing about this plan is that it should be acceptable to everyone. It provides basic coverage to all, regardless of fault, it avoids "socialism", no new board is required and, at the same time, tort

27 Supra, footnote 9.

28 An Act to amend the Alberta Insurance Act, S.A., 1967, c. 39, s. 8, adding a new Part VII; See particularly section $305 \mathrm{c}$ and $305 \mathrm{~d}$. 
law survives, with its many benefits including compensation for pain and suffering. True, it will cost something ${ }^{29}$ to supply these extra benefits, but we should get our money's worth. Indeed, I prophesy that, if this plan is adopted in Alberta, it will become a model for study throughout Canada and the world. Does Alberta dare to be first?

29 The Report of the Automobile Insurance Technical Committee, Ontario Department of Transport (1965) suggested about $20 \%$ of the present premium for liability insurance. around $\$ 10$ for a good risk, for minimum limits. 